\title{
Evolutionary Content Knowledge, Religiosity and Educational Background of Slovene Preschool and Primary School Pre-Service Teachers
}

\author{
Gregor Torkar ${ }^{1 *}$, Andrej Šorgo $^{2}$ \\ 1 University of Ljubljana, SLOVENIA \\ 2 University of Maribor, SLOVENIA
}

Received 14 February 2020 - Accepted 22 March 2020

\begin{abstract}
Evolution by natural selection is the fundamental backbone of the life sciences. Therefore, it is important for teacher education programs to ensure graduates possess a strong knowledge of evolution in order to teach at all levels of biology education. The main aim was to investigate the impacts of the Slovene pre-service preschool and primary school teachers' religiosity and educational background on their evolutionary content knowledge. In the present study, understanding of five evolutionary topics, religiosity and educational background of 269 students was studied. Results show that students have a very poor understanding of evolution. They very often use teleological reasoning. Although many pieces of research have shown that religiosity can be in conflict with evolutionary theory, our findings show that religiosity does not significantly correlate with evolutionary knowledge nor to the educational background of students. However, for students' understanding of evolution, it is important how many years of biology lessons they had in secondary school. This should be better taken into account by educational policymakers because evolutionary principles are becoming increasingly relevant in medicine, agriculture and other socio-scientific topics.
\end{abstract}

Keywords: educational background; evolution knowledge; pre-service teachers; religion; Slovenia

\section{INTRODUCTION}

Evolution by natural selection is one of the most powerful and significant theories in the history of science (Coyne, 2009; Dawkins, 2009) and the unifying paradigm of biology (Dobzhansky, 1973). Despite the clarity of the initial core ideas of Darwin's theory of evolution by natural selection described in On the Origin of Species (Darwin, 1859), misunderstandings about the theory are very abound among students and teachers from different cultural contexts (e.g., Bishop \& Anderson, 1990; Dagher \& BouJaoude, 1997; Fiedler, Tröbst, \& Harms, 2017; Glaze \& Goldston, 2019; Kim \& Nehm, 2011; Nehm, Kim, \& Sheppard, 2009; Nehm \& Reilly, 2007; Nehm \& Schonfeld, 2007; Prinou, Halkia \& Skordoulis, 2011; Rutledge \& Mitchell, 2002; Šorgo et al., 2014; Tavares \& Bobrowski, 2018) and also appear in textbooks (e.g., Aleixandre, 1994; Baptista, da Silva Santos, \& Cobern, 2016; Nehm et al., 2009; Park, 2007;
Prinou, Halkia \& Skordoulis, 2011; Winegard, Winegard \& Deaner, 2014).

This poor understanding has been attributed to diverse cognitive, epistemological, religious, and emotional factors (Rosengren et al., 2012). The sources of flawed knowledge and in some cases total rejection of evolution can be rooted in personal and situational factors. For young children, preschool and early school experiences are very important situational factors because they present the basis for knowledge taught at higher levels of formal education. Thus, early experiences can produce also a number of misconceptions that act as gatekeepers for new insights later in life. It is therefore important for all teachers, teaching about life and living beings, from early childhood to secondary levels, to have a clear understanding of evolution (Vaughn \& Robbins, 2017) in order to prevent that they are a source of misconceptions. 


\section{Contribution to the literature}

- Slovene pre-service teacher's religiosity does not significantly correlate with knowledge about evolution nor to their educational background.

- Number of years of biology education in secondary school positively influence students' understanding of evolution.

Gregory (2009) emphasized that without knowledge of evolution by natural selection, it is impossible for students to understand how or why organisms have come to exhibit their diversity and complexity. Understanding of evolutionary principles is also becoming increasingly relevant in medicine, agriculture and other practical contexts (Gregory, 2009); to mention just resistance to antibiotics (Livermore, 2002) and biocides as flagship cases (Fardisi et al., 2019).

Science classrooms remain one of the few areas where evolution education can take place (Nehm \& Schonfeld, 2007). How a teacher is handling controversy and being able to effectively teach evolutionary ideas are relevant questions for teacher education programs. Many preservice and in-service preschool and primary school teachers do not value evolutionary theory, do not understand the role of it within the curriculum, and some believe that it should not be taught in school (Nadelson \& Nadelson, 2010; Vaughn \& Robbins, 2017). Sickel and Friedrichsen (2013) outlined five goals for preparing teachers to teach evolution: (1) to develop content knowledge of evolution; (2) to develop understandings of the nature of science related to evolution; (3) to develop acceptance of evolution as valid within science; (4) to develop knowledge of and strategies for handling the public controversy; and (5) to develop pedagogical content knowledge for teaching evolution. Many called attention to the necessity for the construction of a notional understructure for teaching evolution, which should be evident from the curricula and textbooks of primary education (e.g., Jeffery \& Roach, 1994; Prinou et al., 2011; Vaughn \& Robbins, 2017; Wagler, 2010). The outlined areas of research are in need of continued pursuit, particularly from Eastern and Central Europe, where little has been published about evolutionary beliefs and proficiency of science teachers (Deniz \& Borgerding (Eds.), 2018; Kim \& Nehm, 2011; Šrorgo et al., 2014).

Prinou and colleagues (2011) analyzed the conceptions held by Greek primary school teachers of the concepts of evolutionary theory. They found that they are not able to adequately introduce the theory of evolution of organisms to pupils. Consequently, no effort is made to question or destabilize the intuitive teleological reasoning of the pupils, and it is carried intact to the next levels of education (Prinou et al., 2011). Similar findings were reported in other countries, like Canada (Asghar, Wiles, \& Alters, 2007) and United States (Nadelson \& Nadelson, 2010; Vaughn \& Robbins,
2017). Nadelson and Nadelson (2010) report that some primary school teachers did not feel prepared or responsible for teaching evolutionary content. A crosscultural study measuring knowledge and beliefs on evolution, genetics, and nature of science involving Turkish, Czech, Slovakian and Slovene first-year university students showed that they, in general, had an alarmingly low level of understanding on evolution. There was a negative impact of religious beliefs on the acceptance of human evolution (Šorgo et al., 2014). Šorgo and colleagues (2014) found that the majority of Slovene students agree that every individual should possess scientific knowledge about human evolution, but they also agree that the alternative evolutionary theories should be taught in schools.

It is essential for teacher education programs to ensure graduates to possess a strong knowledge about evolution and legal issues if associated with teaching evolution (Moore, 2004). Pre-service preschool and primary school teachers are most probably not going to teach children Darwinian evolution, however, they should be aware of evolutionary principles, because they are going to teach about living beings, and paraphrasing Dobzhansky (1973) someone cannot understand life without an understanding of evolution. Therefore, diagnostic assessment of first-year university students would help in planning further steps in the development of preschool and primary school education programs in Slovenia. Some studies (e.g. Vaughn \& Robbins, 2017) show the effectiveness of a curriculum on pre-service teachers' attitudes and knowledge of evolution. Therefore, this is a meaningful way to further improve evolution education, and in the long-term improve public knowledge and acceptance of evolution.

\section{Socio-cultural Context: Slovenia}

Slovenia is a small country in the southern part of Central Europe - in size approximately $20,000 \mathrm{~km}^{2}$, and contains a population of just over two million. The official language is Slovenian and in nationally-mixed regions, Italian and Hungarian are also spoken (About Slovenia - Culture of Slovenia, 2019). A highly literate nation (over 99\%) and highly educated, ranking as the 12th best in the world and 4th best in the European Union (About Slovenia - Culture of Slovenia, 2019). More than half of the Slovenian population actively practices religion. Mostly Roman Catholicism (57.8\%), Islam $(2.4 \%)$, Eastern Orthodoxy $(2.3 \%)$, and Lutheranism $(0.8 \%)$. Some $(2.3 \%)$ are believers, who adhere to no 
religion. For $7.3 \%$ of the population, the information is unknown. And there is $25.9 \%$ of the population, who are non-religious or refused to answer (Črnič, Komel, Smrke, Šabec \& Vovk, 2013). According to the results of the latest study about youths in Slovenia (Naterer et al., 2019) in the age group between 16 and 27 years old, 52\% declared themselves as Catholics, $10 \%$ as members of other religious groups, and $38 \%$ as non-believers. Among them, $44 \%$ declared that they never participated in organized religious activities. Slovenia has historically been the crossroads of Slavic, Germanic, and Romanic languages and cultures, which coexisted for centuries together in these parts of Europe, and have contributed significantly to Slovenian society.

In Slovenia, pre-school education is optional. Children can enrol as early as at the age of 11 months and attend it until they start compulsory school. It is worth to be mentioned that the majority of kindergartens are public and subsidized by local communities and that all public kindergartens follow a curriculum approved by governmental bodies. Nine-year compulsory school is divided into three three-year cycles (for students six to fourteen years old). It is mandatory, 99 percent public, and state-financed. The first six years can be recognized as the primary (ISCED 1) level. Grades 7-9 are internationally recognized as the lower secondary school (ISCED 2). Upon completion of compulsory basic education, students - typically aged 15 - may choose to continue their education at the upper secondary level at a school and a programme of their own choice (ISCED 3) (from two up to five years to complete). Upper secondary education programmes are either general or vocational. The upper secondary educational qualification is awarded only after passing the final examination (matura, leaving examination) that grants also the right to enrol in higher levels. Students can enrol to preschool education programme with general or vocational matura, and to primary school education bachelor programme with general matura (Eurydice, 2019).

Biology learning objectives are already included in the curriculum for pre-school education, in one of six programs named Nature. In nine-year compulsory school biology education is included in four compulsory school subjects: Learning about the environment (first, second and third grade), Science and Technology (fourth and fifth grade), Science (sixth and seventh grade), and Biology (eighth and ninth grade). Physics and Chemistry are also compulsory subjects in the last two grades. Biology education is also a part of upper secondary education in subjects of Biology, Science or Science and Society, depending on the program. For example, in $2015,36 \%$ of students were enrolled in general upper secondary schools, where they follow biology courses for three or four years. The rest of the students' population is in the vocational and technical education, where biology related courses vary from zero to four years (Eurydice, 2019).

Education staff at preschool and school level have to hold relevant educational qualification (ISCED 6 for preschool teachers, ISCED 7 for primary school and other teachers) and they have to pass the state professional examination for education staff (Eurydice, 2019). Even though the curriculum varies among universities, preservice pre-school teachers typically take content knowledge courses (general biology / chemistry / physics), pedagogical content knowledge courses, and general education courses. Students learn basics about evolution in general biology courses. A primary teacher certificate is typically acquired through a three or fouryear Bachelor of Education program, followed by a oneor two-year Master of Education program. Altogether to be allowed to enter a classroom pre-service teachers should collect 300 ECTS. Similarly, the curricula vary among universities. Pre-service primary school teachers typically take content knowledge courses (general biology / chemistry / physics), pedagogical content knowledge courses, general education courses, and work at schools. They learn basics about evolution in general biology (science) courses.

Biological evolution is included in the Slovene national curriculum at the end of compulsory school (ninth grade) and at the upper secondary school levels and is taught by one or two streams Biology teachers. Ninth-grade students are required to learn the evidence that supports the scientific concept of evolution and the basic mechanisms of evolution, such as natural selection, mutations, recombination, and variability. They also learn about the evidence that supports human evolution. At the upper secondary school level, students learn about the origin of species and evolution in greater depth, but usually, only students of a general upper secondary school (general programme) learn about evolution in greater detail. Knowledge of students of vocational and technical secondary schools rely mainly on evolution learned in the ninth grade of compulsory school.

\section{Research Questions}

The overarching goal of the present study was to investigate Slovene pre-service preschool and primary school teachers' understanding of evolution in association with religiosity and educational backgrounds. The lack of understanding of evolution, and consequently the ability to effectively teach the topic and problems with regard to the acceptance of evolution as the main unifying paradigm in biology, and the fact that many people believe it contradicts their religious beliefs, are the main triggers for conducting the present research. Specifically, three research questions were formed: 
Table 1. Description of the participants

\begin{tabular}{llcc}
\hline Variables & & $f$ & $f \%$ \\
\hline University of & Ljubljana & 119 & 44.2 \\
& Maribor & 150 & 55.8 \\
Study programme & Preschool education & 98 & 36.4 \\
& Primary school & 171 & 63.6 \\
Age & education & & \\
& 19 & 133 & 49.4 \\
& 20 & 92 & 34.2 \\
& 21 & 9 & 3.3 \\
Fender & 22 & 27 & 10.0 \\
Faith & 23 & 4 & 1.5 \\
& 24 & 1 & .4 \\
& 25 & 1 & .4 \\
& Missing information & 2 & .7 \\
& Male & 22 & 8.2 \\
& Female & 247 & 91.8 \\
& Catholic & 215 & 79.9 \\
& Orthodox & 2 & .7 \\
& Protestant & 4 & 1.5 \\
& Muslim & 2 & .7 \\
Years of biology & Iskcon & 1 & .4 \\
education in & Non-believer, atheist & 35 & 13.0 \\
secondary school & 2 & 10 & 3.7 \\
& No answer & 10 & 3.7 \\
& 4 & 103 & 38.3 \\
& & 122 & 45.4 \\
& & 34 & 12.6 \\
\hline \multirow{4}{*}{ (1) } & & \\
& & &
\end{tabular}

RQ1: Do Slovene pre-service preschool and primary school teachers understand some essential concepts about evolution: adaptation, fitness, heritable traits, natural selection, and evolutionary tree (cladogram)?

RQ2: Does evolutionary content knowledge differ with regard to the religiosity?

RQ3: Does evolutionary content knowledge differ with regard to the educational background?

\section{METHODS}

\section{Participants}

Participants $(\mathrm{N}=269)$ included cohorts of pre-service teachers in bachelor programs majoring in preschool and primary school education at the University of Ljubljana and the University of Maribor (both in Slovenia). All participating students were in their first year (preservice primary school teachers) or second year (preservice preschool teachers) of studies and prior they were taught biology at the University. The sample details are presented in Table 1.

\section{Instrument and Procedure}

Sampling was performed by the supervision of teaching staff during science lectures or laboratory sessions in the study year 2018-19. Students needed approximately 20-30 minutes to complete the survey. Participation was voluntary and anonymous, and no benefits were offered to the participants. According to Slovenian rules, such kinds of surveys do not need the approval of an ethical or similar body.

The instruments from Beniermann (2019) and Kuschmierz et al. (2020) were translated and retranslated in Slovenian language by the university teachers of biology education and evolutionary courses. First demographic questions (age and gender) were asked, followed by question on educational background prior entering the university (the number of years of biology in upper secondary school), knowledge questions (items taken from the KAEVO 2.0 "Knowledge About EVOlution" instrument, Kuschmierz et al., 2020; part A: eight multiple-choice questions about adaptation, natural selection, fitness, heritable traits, and evolutionary tree; a set of possible answers for each question are presented in Tables 2-9) and religiosity questions to quantify religious faith (the PERF "PErsonal Religious Faith" scale; Beniermann, 2019). The level of religiosity was assigned from ten items on the Likert scale: $1=$ completely agree, $5=$ completely disagree, e.g. I feel that God exists, I would describe myself as a religious person, I believe that heaven exists, etc. Next, to assess the frequency of their participation in organized religious activities of their religious community they should check a box with three options: a) never, b) occasionally (few times in a year), c) often (monthly or more often).

All statistical analyses were conducted with IBM SPSS Statistics 22. Descriptive statistics $(f, f \%, M, S D)$ were calculated. Relationships between evolutionary content knowledge, religiosity, and educational background were analyzed using Spearman's two-tailed rank correlation coefficient.

\section{RESULTS}

Three multiple-choice questions explored their understanding of adaptation and natural selection, followed by one question about fitness, two questions about heritable traits and final two questions about the evolutionary tree.

First, students were asked to explain how the Venus flytrap developed over time specifically adapted trapping leaves which plant can also use to feed on insects. They were asked to select the most correct statement presented in Table 2. Results show that only $17.8 \%$ of students selected correct answers that some flytraps randomly had trapping leaves and more of them were able to survive and reproduce. Most frequently $(29.4 \%)$ mentioned incorrect explanation was that flytraps recognize the nutrient deficiencies and in response transform their leaves into trapping leaves.

Next, students were asked to explain how the desert plants survive with little water. They were told that "throughout the day, it is hot and the sun shines with great intensity. For many plants, this is bad, because they 
Table 2. The Venus flytrap question (KAEVO 2.0 instrument; Kuschmierz et al., 2020)

\begin{tabular}{|c|c|c|}
\hline Statements & $f$ & $f \%$ \\
\hline $\begin{array}{l}\text { Some Venus flytraps recognized the nutrient deficiencies and transformed their leaves in response into trapping } \\
\text { leaves. As a result, they could also feed on insects and survived with greater ease. }\end{array}$ & 79 & 29.4 \\
\hline $\begin{array}{l}\text { Because of the nutrient deficiency, the Venus flytraps automatically received their trapping leaves. Hence, they } \\
\text { had a survival advantage. }\end{array}$ & 37 & 13.8 \\
\hline Nature has adapted the Venus flytraps to the nutrient-deficient soil, so they can grow better. & 33 & 12.3 \\
\hline $\begin{array}{l}\text { Some Venus flytraps randomly had trapping leaves and additionally were able to consume insects on the } \\
\text { nutrient deficient soil. Therefore, more Venus flytraps with trapping leaves were able to survive and reproduce. }\end{array}$ & $\underline{48}$ & $\underline{17.8}$ \\
\hline In order to grow better, the Venus flytraps adapted to the nutrient-deficient soil. & 57 & 21.2 \\
\hline I do not know / No answer & 15 & 5.6 \\
\hline Total & 269 & 100.0 \\
\hline
\end{tabular}

Table 3. The leafless cactus with thorns question (KAEVO 2.0 instrument; Kuschmierz et al., 2020)

\begin{tabular}{|c|c|c|}
\hline Statements & $f$ & $f \%$ \\
\hline In order to lose less water, the cacti adapted to the desert habitat. & 92 & s34.2 \\
\hline $\begin{array}{l}\text { Some cacti with leaves recognized that they lost too much water. Hence, they shrunk their leaves. As a result, they } \\
\text { lost less water and were able to survive more easily. }\end{array}$ & 25 & 9.3 \\
\hline $\begin{array}{l}\text { Some cacti randomly had smaller leaves and lost less water in the desert. Consequently, more cacti with smaller } \\
\text { leaves were able to survive and reproduce. }\end{array}$ & $\underline{57}$ & $\underline{21.2}$ \\
\hline $\begin{array}{l}\text { The cacti had smaller leaves automatically because they lost less water in the desert this way. Hence, they had a } \\
\text { survival advantage. }\end{array}$ & 29 & 10.8 \\
\hline Nature has adapted the cacti to its desert habitat, so they lose less water. & 53 & 19.7 \\
\hline I do not know / No answer & 13 & 4.8 \\
\hline Total & 269 & 100.0 \\
\hline
\end{tabular}

Table 4. The banded snail question (KAEVO 2.0 instrument; Kuschmierz et al., 2020)

\begin{tabular}{|c|c|c|}
\hline Statements & $f$ & $f \%$ \\
\hline $\begin{array}{l}\text { Since this was a better way to hide from the song thrushes, the light-colored snails changed their color } \\
\text { automatically. Hence, they had a survival advantage. }\end{array}$ & 27 & 10.0 \\
\hline Nature has adapted the light-colored snails to the habitat (meadows), so they have a better camouflage. & 76 & 28.3 \\
\hline $\begin{array}{l}\text { Some dark-colored snails recognized that they had to change their color in order to have a better camouflage. } \\
\text { Therefore, they ate more light-colored food in order to change their shells into a lighter color. }\end{array}$ & 11 & 4.1 \\
\hline In order to have a better camouflage, the light-colored snails adapted to the habitat (meadow). & 16 & 5.9 \\
\hline $\begin{array}{l}\text { Some dark-colored snails recognized that they had to change their color in order to have a better camouflage. } \\
\text { Therefore, they changed their color. As a result, they were eaten less frequently and were able to survive more } \\
\text { easily. }\end{array}$ & 20 & 7.4 \\
\hline $\begin{array}{l}\text { Some snails randomly had a lighter colour and were not spotted so easily (on the meadow) by the song thrushes. } \\
\text { Therefore, more light coloured snails were able to survive and reproduce. }\end{array}$ & $\underline{98}$ & $\underline{36.4}$ \\
\hline I do not know / No answer & 21 & 7.8 \\
\hline Total & 269 & 100.0 \\
\hline
\end{tabular}

lose a lot of water due to the heat and the dry air. From cacti with leaves, first cacti with smaller leaves and then leafless cacti with thorns developed." They had to explain how this happened. They were asked to select the most correct statement presented in Table 3. Like in the previous question, results for cactus show low understanding $(21.2 \%)$ of adaptation among students. Students most often (34.2\%) selected incorrect explanations that the cacti adapted to the desert habitat in order to lose less water.

In the third question, students were asked about shells of banded snails, which can vary in colour. Students were informed that in the forest, where the ground tends to be browner, snails with dark shells more frequently live. Snails with lighter colors more frequently live on meadows. This is a better camouflage to hide from their predators. They were asked to explain, how this happens, by selecting the most correct statement in Table 4. Results show that one-third of students selected a correct statement that some snails randomly had a lighter color and were not spotted so easily on the meadow by predators, and therefore, more of them were able to survive and reproduce. More than a quarter of students (28.3\%) selected as the most accurate explanation that nature has adapted the lightcolored snails to meadows, so they have a better camouflage.

In the question about fitness, some characteristics of four male lions (George, Ben, Spot, and Sandy) were presented (Table 5). Students had to determine which of 
Table 5. The fittest lion (KAEVO 2.0 instrument; Kuschmierz et al., 2020)

\begin{tabular}{lc}
\hline Statements & $f$ \\
\hline Male lion: George & $5 \%$ \\
Male lion: Ben & 21.2 \\
Male lion: Spot & 25.3 \\
Male lion: Sandy & 68 \\
I do not know / No answer & 116 \\
Total & $\frac{43.1}{10}$ \\
\hline
\end{tabular}

Table 6. The August Weismann - first question (KAEVO 2.0 instrument; Kuschmierz et al., 2020)

\begin{tabular}{|c|c|c|}
\hline Statements & $f$ & $f \%$ \\
\hline On average, their tails would be a little shorter than the tails of the parents. & 23 & 8.6 \\
\hline They would still have a tail that would not be used anymore. & 24 & 8.9 \\
\hline They would have no tail. & 4 & 1.5 \\
\hline Cutting off the tails would not have an effect on the offspring's tail length. & $\underline{200}$ & $\underline{74.3}$ \\
\hline I do not know / No answer & 18 & 6.7 \\
\hline Total & 269 & 100.0 \\
\hline
\end{tabular}

Table 7. The August Weismann second question (KAEVO 2.0 instrument; Kuschmierz et al., 2020)

\begin{tabular}{|c|c|c|}
\hline Statements & $f$ & $f \%$ \\
\hline On average, their tails would be significantly shorter as the tails of the parents from the first generation. & 58 & 21.6 \\
\hline They would still have a tail that would not be used anymore. & 65 & 24.2 \\
\hline They would have no tail. & 22 & 8.2 \\
\hline Cutting off the tails would not have an effect on the offspring's tail length. & $\underline{99}$ & $\underline{36.8}$ \\
\hline I do not know / No answer & $\overline{25}$ & 9.3 \\
\hline Total & 269 & 100.0 \\
\hline
\end{tabular}

them is the fittest by comparing their length with tail, weight, age at death, a number of cubs the male is father to and how many of them survived to adulthood. In addition, some comments were provided about their life and death. The correct answer was lion Sandy who had the largest number of cubs surviving to adulthood. Only ten $(3.7 \%)$ students selected the correct answer. Three other answers were much more attractive to students. Very frequently (43.1\%) students selected a male lion named Spot who was not the largest, the heaviest nor had the most cubs, but in the comment was explained that "the area that Spot lived in was destroyed by fire, he was able to move to a new area and change his feeding habits". One-quarter of students $(25.3 \%)$ selected male lion named Ben, who was the father to the largest number of cups (but not to cubs reaching adulthood) and the greatest number of females in his harem. Frequently $(21.2 \%)$ selected was also a male lion named George, who was the largest, heaviest and strongest.

Students were presented with the story of the $19^{\text {th }}$ century zoologist August Weismann, who conducted the experiment in which he completely cut off the tail of mice in order to determine which consequences this might have on the mice's direct offspring. Students were asked to explain, how would the offspring of mice look like. They were asked to select the most correct statement presented in Table 6 . The majority $(74.3 \%)$ of students selected the correct answer.

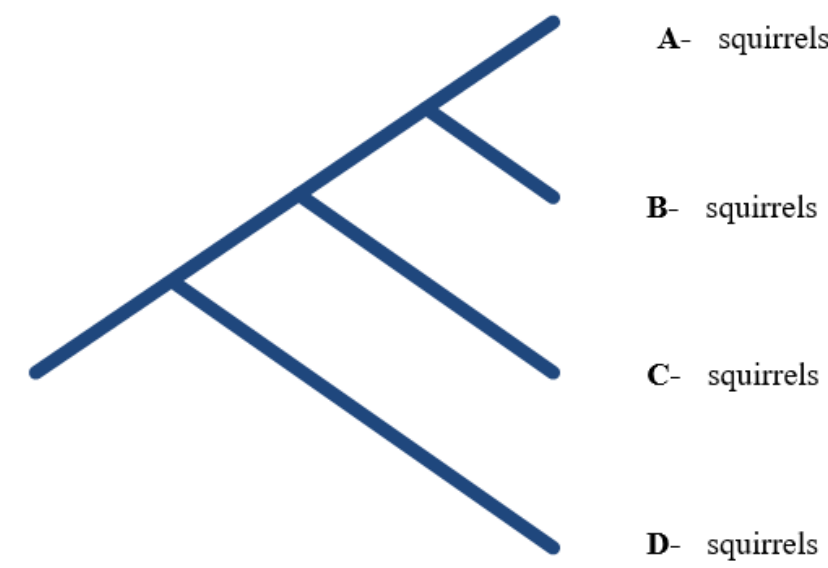

Figure 1. Evolutionary tree (cladogram) (KAEVO 2.0 instrument; Kuschmierz et al., 2020)

In the following question, students had to again refer to the story of zoologist August Weismann. They had to assume that Weismann would have cut off the offspring's tails and their descendants etc., for a total of 20 generations. Students had to predict how the mice of the 21st generation would look like. They were asked to select the most correct statement presented in Table 7. One-third of students $(36.8 \%)$ correctly answered. Students alternatively often selected explanation stating the tails of offspring would be shorter $(21.6 \%)$ or not functional $(24.2 \%)$, showing that they learned a difference between inherited and acquired traits, however without the understanding of the difference. 
Table 8. Evolutionary tree (cladogram) - the first question (KAEVO 2.0 instrument; Kuschmierz et al., 2020)

\begin{tabular}{|c|c|c|}
\hline Statements & $f$ & $f \%$ \\
\hline a (vertical up) & 7 & 2.6 \\
\hline b (vertical down) & 16 & 5.9 \\
\hline$\underline{c}$ (horizontal right) & $\underline{12}$ & $\underline{4.5}$ \\
\hline d (horizontal left) & 1 & .4 \\
\hline e (sloped up right) & 56 & 20.8 \\
\hline $\mathrm{f}$ (sloped down left) & 62 & 23.0 \\
\hline g (sloped down right) & 63 & 23.4 \\
\hline h (sloped up left) & 2 & .7 \\
\hline I do not know / No answer & 50 & 18.6 \\
\hline Total & 269 & 100.0 \\
\hline
\end{tabular}

Table 9. Evolutionary tree - second question (KAEVO 2.0 instrument; Kuschmierz et al., 2020)

\begin{tabular}{|c|c|c|}
\hline Statements & $f$ & $f \%$ \\
\hline ... most closely related to A-squirrels. & 30 & 11.2 \\
\hline ... most closely related to B-squirrels. & 34 & 12.6 \\
\hline ... most closely related to D-squirrels. & 24 & 8.9 \\
\hline$\ldots$ as closely related to A-squirrels as to B-squirrels. & $\underline{16}$ & $\underline{5.9}$ \\
\hline$\ldots$ as closely related to B-squirrels as to D-squirrels. & 83 & 30.9 \\
\hline ... as close related to A-squirrels as to B-squirrels and D-squirrels. & 12 & 4.5 \\
\hline I do not know / No answer & 70 & 26.0 \\
\hline Total & 269 & 100.0 \\
\hline
\end{tabular}

Table 10. The total score on the evolutionary content knowledge

\begin{tabular}{lcc}
\hline Score (points) & $f$ & $f \%$ \\
\hline 0 & 30 & 11.2 \\
1 & 80 & 29.7 \\
2 & 79 & 29.4 \\
3 & 39 & 14.5 \\
4 & 24 & 8.9 \\
5 & 14 & 5.2 \\
6 & 2 & .7 \\
7 & 1 & .4 \\
8 & 0 & 0 \\
Total & $\mathbf{2 6 9}$ & $\mathbf{1 0 0 . 0}$ \\
\hline
\end{tabular}

In the next two questions, students had to show their understanding of the evolutionary tree (cladogram) (Figure 1). They first had to explain which arrow shows correctly the time axis of the event (development of four squirrel species) shown in the tree (Table 8). Horizontal arrow (answer c) was correct and twelve students (4.5\%) selected the correct answer. Students of the mistakenly selected arrows sloped upright $(20.8 \%)$, sloped down right $(23.1 \%)$ and sloped down left $(23.4 \%)$.

In the second question, referring to the evolutionary tree, students had to show their understanding of relatedness among squirrels. They had to choose which squirrels are the most related to C - squirrels (Table 9). Similarly, very few students correctly answered to the second question (5.9\%). More than a quarter $(26.0 \%)$ did not provide an answer and $30.9 \%$ of students responded that they are as closely related to A-squirrels as to Bsquirrels and D-squirrels.
Table 11. Students' practices of religion

\begin{tabular}{llcc}
\hline Variables & & $f$ & $f \%$ \\
\hline Actively practices Never & 29 & 10.8 \\
religion & Few times a year & 120 & 44.6 \\
& Monthly or more often & 76 & 28.3 \\
& No answer & 44 & 16.4 \\
& Total & $\mathbf{2 6 9}$ & $\mathbf{1 0 0 . 0}$ \\
\hline
\end{tabular}

Overall, students showed very poor knowledge and understanding of evolutionary content. Not even one student correctly answered all eight questions and $11.2 \%$ collected zero points (Table 10).

Ten items (PERF scale; Beniermann, 2019) were used to measure students' religiosity (descriptive statistics is presented in Appendix, Table 1). Cronbach's Alpha for ten items on religiosity is 0.97 . Mean score for ten items is $2.98(\mathrm{SD}=1.30)$. Table 11 shows that $28.3 \%$ of students practice religion monthly or more often.

Students' total score in evolutionary content knowledge, mean score in religiosity, active religious practices and educational background (years of biology in upper secondary school) were correlated (Table 12). While we found no relationship between the factors religiosity and evolutionary knowledge or religiosity and educational background, positive correlations between educational background and evolutionary knowledge were detected $\left(\mathrm{r}_{\mathrm{s}}=.234, \mathrm{p}<.001\right)$. There is also a strong positive correlation between religiosity and frequency of practicing religion $\left(\mathrm{r}_{\mathrm{s}}=-.577, \mathrm{p}<.001\right)$. From the results, it is obvious, that only educational background has a positive impact on knowledge, while religiosity does not. 
Table 12. Correlations between evolutionary content knowledge, religiosity, and educational background

\begin{tabular}{|c|c|c|c|c|c|}
\hline & Spearman's rho & $\begin{array}{l}\text { Educational } \\
\text { background }\end{array}$ & Religiosity & $\begin{array}{c}\text { Active religious } \\
\text { practices }\end{array}$ & $\begin{array}{c}\text { Evolutionary } \\
\text { knowledge }\end{array}$ \\
\hline \multirow{3}{*}{$\begin{array}{l}\text { Educational } \\
\text { background }\end{array}$} & $r_{s}$ & 1.000 & .069 & 0.18 & $.234^{* *}$ \\
\hline & $p$ & & .266 & .791 & .000 \\
\hline & $N$ & 269 & 262 & 225 & 269 \\
\hline \multirow[t]{3}{*}{ Religiosity } & $r_{s}$ & .069 & 1.000 & $-.577^{* *}$ & .015 \\
\hline & $p$ & .266 & . & .000 & .808 \\
\hline & $N$ & 262 & 262 & 225 & 262 \\
\hline \multirow{3}{*}{$\begin{array}{l}\text { Active religious } \\
\text { practices }\end{array}$} & $r_{s}$ & 0.18 & $-.577^{* *}$ & 1.000 & .004 \\
\hline & $p$ & .791 & .000 & . & .947 \\
\hline & $N$ & 225 & 225 & 225 & 225 \\
\hline \multirow{3}{*}{$\begin{array}{l}\text { Evolutionary } \\
\text { knowledge }\end{array}$} & $r_{s}$ & $.234^{* *}$ & .015 & .004 & 1.000 \\
\hline & $p$ & .000 & .808 & .947 & $\cdot$ \\
\hline & $N$ & 269 & 262 & 225 & 269 \\
\hline
\end{tabular}

**Correlation is significant at the 0.001 level (2-tailed).

\section{DISCUSSION}

Slovene pre-service preschool and primary school teachers were sampled at the beginning of their undergraduate programs, before starting taking any lessons in science and biology. Therefore, results, accessible in the present research, reflect their knowledge after finishing secondary school. The gender ratio in this sample closely aligns with those of the larger population of teachers in Slovenia. Slovenia has a high proportion of women among primary school teachers, 97.5\% (Eurostat, 2013).

\section{Knowledge of Evolution}

Items taken from the KAEVO 2.0 instrument (Kuschmierz et al., 2020) measured pre-service teachers' understanding of some essential concepts about evolution: adaptation, natural selection, fitness, heritable traits, and evolutionary tree (cladogram). Overall, results show a very poor (scientifically incomplete or incorrect) understanding of evolution. This is in line with the study by Šorgo et al. (2014) showing that firstyear university students from four different European countries, including Slovenia, had an alarmingly low level of understanding of evolution. Similar findings were reported also for pre-service teachers (e.g., Tavares \& Bobrowski, 2018), primary school teachers (e.g., Prinou et al., 2011) and biology teachers (e.g., Nehm, Kim, \& Sheppard, 2009) elsewhere.

Results for pre-service teachers' understanding of adaptation and natural selection revealed that they often use teleological (goal-directed) reasoning regarding the origin of biological adaptations. Such type of reasonings is popular among both children and adults, as they are useful for describing, explaining, and understanding what is going on in the world around us (Stern et al., 2018). Teleologically oriented thinkers are often framed in terms of change occurring as a result of particular need, but in reality, natural selection does not have a directed goal or telos (Gregory, 2009). Teleological reasoning is a pervasive feature of human cognition that transcends culture and religion. It is believed to be a major barrier to normative evolutionary understanding (Kelemen, 2012). Many students in the present research understood the word adaptation in its everyday context - as individuals changing in response to the environment and as simultaneous changes in population, rather than as a random process and natural selection (Bishop \& Anderson, 1990). For example, “In order to lose less water, the cacti adapted to the desert habitat." Many also think that organisms develop new traits because they need them to survive. For example, "Some Venus flytraps recognized the nutrient deficiencies and transformed their leaves in response to trapping leaves. As a result, they could also feed on insects and survived with greater ease."

The question about the fittest male lion explored students' understanding of the role survival and reproduction have in evolution. Al-Shawaf, Zreik, and Buss (2018) wrote that it is common to think that natural selection is primarily about survival, but in reality, reproduction is more important than survival. Differential reproductive success is the key to change in evolution. This confusion was also detected in the results of the present research, where students regularly selected lions who were the largest, heaviest, oldest, healthiest and strongest, with most females... and not the one with the most cubs surviving to adulthood.

When presented with the story of the 19th-century zoologist August Weismann, explaining heritable traits, the majority of students selected a correct answer on the first question. We can safely conclude that the reason for relatively good results is rooted in previous education because the vignette about mice is part of literally all Slovene biology textbooks, where the difference between the Lamarckian and Darwinian theory of evolution is explained. Students have obviously remembered it. However, many answers of students to the second question about the hypothetical Weismann's experiment imply that acquired traits, by cutting "off the offspring's tails and their descendants, etc., for a total of 20 
generations", can be inherited. Almost half of the students selected the answers implying this: "On average, their tails would be a little shorter than the tails of the parents." or "They would still have a tail which would not be used anymore.". This is often called "soft inheritance" (Gregory, 2009), i.e. that characteristics acquired during the lifetime of an individual can be transmitted to the offspring.

The present research also examined students' knowledge of evolutionary (phylogenetic) tree, a key subcomponent of macroevolution (Catley, 2006) and a vital component of science literacy in the 21st century (Novick \& Catley, 2016). To understand evolutionary (phylogenetic) trees, a student needs "tree thinking", as has been coined a term to describe the ability to conceptualize evolutionary relationships among taxa (Meisel, 2010). Misunderstandings about evolutionary trees are very persistent among students and nonspecialists (e.g., Baum, DeWitt Smith, \& Donovan, 2007; Dees, Momsen, Niemi, \& Montplaisir, 2014; Gregory, 2008; Novick \& Catley, 2013; Perry, Meir, Herron, Maruca, \& Stal, 2008). Baum, DeWitt Smith and Donovan (2007) found that many people spontaneously interpret closer relatedness among terminal nodes according to their order rather than assessing the pattern of branching. Similar was observed in the second question referring to the cladogram of squirrels. They also misread the time axis on the cladogram. This misconnection was already reported by Meir, Perry, Herron and Kingsolver (2007). The only correct explanation is that time extends from the root to the terminal nodes, all of which are contemporary (Gregory, 2008).

Student misconceptions regarding evolution are very resistant to instruction (Gregory, 2009), but can be improved with the series of activities and teaching strategies (e.g. Dees, Momsen, Niemi, \& Montplaisir, 2014; Kalinowski, Leonard, Andrews, \& Litt, 2013; Kampourakis \& Zogza, 2008; Nehm and Schonfeld, 2007; Pope, Rounds, \& Clarke-Midura, 2017). Nehm and Schonfeld (2007) found that students tend to retain only what is necessary to pass the exam before returning back to their original beliefs about evolution. Therefore, more attention should be given to longitudinal studies assessing the changes in the understanding of evolution.

\section{Influence of Religiosity}

The sample of pre-service teachers is more religious than the general Slovene population and predominantly Christian - for comparison with the Slovene population see Černič et al. (2013) and Naterer et al. (2019). We cannot explain the reasons for a higher percentage of religious pre-service teachers in our sample when compared with the general population of youth. Therefore, reasons for a high percent of religious preservice teachers must be further analysed to address the possible explanations and implications for formal education.

Theism is an important aspect of worldview for many pre-service preschool and primary school teachers in Slovenia. According to theism, God exists, created the universe and the living things, there is life after death, and ethics originate from God (Anderson, 2007). Although many have shown that religious affiliation and religiosity can be in conflict with evolutionary theory (e.g. Deniz \& Sahin, 2016; Nehm \& Schonfeld, 2007; Rachmatullah, Nehm, Roshayanti, \& Ha 2018; Trani, 2004), our findings show that religiosity does not statistically significantly correlate with evolutionary knowledge nor with the educational background of students. Similarly, Athanasiou and Papadopoulou (2015) also report no significant correlation between the frequency of religion practicing and the level of understanding of evolution theory among Greek preservice teachers. Kim and Nehm (2011) found no significant main effect of the Christian religion on Korean science teachers' knowledge of evolution. For Malaysian teachers, Yok and colleagues (2015) report that they can accept and teach evolution, but at the same time believe that the processes of evolution are controlled by God. If we can achieve an understanding of evolution as the path that "leads to an acceptance of evolution as the best explanation for the evidence we find, then there is no need to challenge belief in a creator God" (Williams, 2015, p. 332), this will simply enable students to understand the scientific worldview with respect to origins of life, not necessarily to accept it.

\section{Influence of Educational Background}

Kim and Nehm (2011) found no significant main effect of their certification area (biology, chemistry, physics or earth science education) on Korean science teachers' evolution content knowledge. On the contrary, Großschedl, Mahler and Harms (2018) report that the type of teacher education program pre-service teachers attend influences their knowledge about evolution - preservice teachers of the academic track performed better in content knowledge test than their non-academic colleagues. In light of the above, we can see that our findings show a small positive effect of pre-service preschool and primary school teachers' number of years of biology in secondary school on their understanding of evolution.

Sickel and Friedrichsen (2013) stressed the need for pursuing research investigating the nature of teachers' acceptance of evolution and pedagogical content knowledge for teaching evolution. Many suggest that teaching approaches should include a focus on misconceptions about evolution (e.g., Gregory, 2009; Walter, Halverson, \& Boyce, 2013). According to Nehm et al. (2009), the central goal should be the desegregation of evolution as separate sections or chapters in curricula and textbooks, and the active integration of evolutionary 
concepts at all levels and across all domains of biology education. Theory of evolution should be perceived by students as a classical model of scientific reasoning that can help students "to appreciate the way science is done, the procedures by which scientific knowledge accumulates, the limitations of science and the ways in which scientific knowledge differs from other forms of knowledge" (Reiss, 2018). Last but not least, teachers play an important role in students' perception of biology (Kubiatko, Torkar, \& Rovnannova, 2017), therefore, studying teacher's pedagogical content knowledge and promoting efficient teaching practices is essential, especially when discussing socio-scientific topics in the classroom; these are certainly some questions about evolutionary theory and its acceptance in society.

\section{CONCLUSION}

The main research goal of the present study was to investigate Slovene pre-service preschool and primary school teachers' understanding of evolution in association with religiosity and educational backgrounds. The number of years of biology lessons in upper secondary school significantly correlates with their understanding of evolution. Their religiosity is not an important predictor. Research on this issue inevitably has some limitations. Firstly, the research was only completed in the two largest universities in Slovenia and only in one study year. Next, students' understanding of the theory of evolution was measured only with eight questions, therefore, limited conclusions and generalization regarding the understanding of evolution can be drawn from the research. For further research, however, it would be good to study in more detail preservice teachers' understanding of evolution, because they have a very significant role in public understanding and acceptance of the evolutionary theory. The findings of the present study should be taken into account by educational policymakers because evolutionary principles are becoming increasingly relevant in medicine, agriculture and other socio-scientific issues. Current trends in national curriculum changes (estimated by authors for the last twenty years), the number of hours of biology instruction in primary and secondary schools (particularly vocational) is decreasing.

\section{ACKNOWLEDGEMENTS}

We would like to thank Paul Kuschmierz who invited us to international research. Our work partially follows the goals of the Work Group 1 ("Assessment of attitudes and knowledge about evolution across Europe" led by Dr. Anna Beniermann) in the EU funded COST Action CA17127 "Building on scientific literacy in evolution towards scientifically responsible Europeans".

\section{REFERENCES}

About Slovenia - Culture of Slovenia (2019). Retrived from https://www.culture.si/en/Slovenia\# Education

Aleixandre, M. P. J. (1994). Teaching evolution and natural selection: a look at textbooks and teachers. Journal of Research in Science Teaching, 31(5), 519-535. https:/ / doi.org/10.1002/tea.3660310507

Al-Shawaf, L., Zreik, K., \& Buss, D. M. (2018). Thirteen misunderstandings about natural selection. Encyclopedia of Evolutionary Psychological Science, 114.

Anderson, R. D. (2007). Teaching the theory of evolution in social, intellectual, and pedagogical context. Science Education, 91(4), 664-677. https://doi.org/ 10.1002 / sce. 20204

Asghar, A., Wiles, J. R., \& Alters, B. (2007). Canadian preservice elementary teachers'conceptions of biological evolution and evolution education. McGill Journal of Education (Online), 42(2), 189.

Athanasiou, K., \& Papadopoulou, P. (2015). Evolution theory teaching and learning: What conclusions can we get from comparisons of teachers' and students' conceptual ecologies in Greece and Turkey?. Eurasia Journal of Mathematics, Science $\mathcal{E}$ Technology Education, 11(4), 841-853. https://doi.org/ 10.12973/eurasia.2015.1443a

Baptista, G. C. S., da Silva Santos, R., \& Cobern, W. W. (2016). Perspectives on the Origins of Life in Science Textbooks from a Christian Publisher: Implications for Teaching Science. International Journal of Science and Mathematics Education, 14(2), 309-326. https:/ / doi.org/10.1007/s10763-015-9641-6

Baum, D. A., Smith, S. D., \& Donovan, S. S. (2005). The tree-thinking challenge. Science, 310(5750), 979-980. https:/ / doi.org/10.1126/science.1117727

Beniermann, A. (2019). Evolution - von Akzeptanz und Zweifeln - Empirische Studien über Einstellungen zu Evolution und Bewusstsein [Evolution - of acceptance and doubts. Empirical studies on attitudes towards evolution and the evolution of the human mind]. Veröffentlichung der Dissertation, Wiesbaden: Springer Spektrum. https: / / doi.org/10.1007/978-3-658-24105-6

Bishop, B. A., \& Anderson, C. W. (1990). Student conceptions of natural selection and its role in evolution. Journal of research in science teaching, 27(5), 415-427. https://doi.org/10.1002/tea. 3660270503

Catley, K. M. (2006). Darwin's missing link-a novel paradigm for evolution education. Science Education, 90(5), 767-783. https:/ / doi.org/10.1002/ sce.20152 
Coyne, J. A. (2010). Why evolution is true. Oxford University Press.

Črnič, A., Komel, M., Smrke, M., Šabec, K., \& Vovk, T. (2013). Religious Pluralisation in Slovenia. Teorija in praksa, 50, 205-32.

Dagher, Z. R., \& BouJaoude, S. (1997). Scientific views and religious beliefs of college students: The case of biological evolution. Journal of Research in Science Teaching, 34(5), 429-445. https://doi.org/10.1002/ (SICI)1098-2736(199705)34:5<429::AID-TEA2>3.0.C $\mathrm{O} ; 2-\mathrm{S}$

Darwin, C. (2004). On the origin of species, 1859. Routledge. https://doi.org/10.4324/97802035091 04

Dawkins, R. (2009). The greatest show on earth: The evidence for evolution. Simon and Schuster.

Dees, J., Momsen, J. L., Niemi, J., \& Montplaisir, L. (2014). Student interpretations of phylogenetic trees in an introductory biology course. CBE-Life Sciences Education, 13(4), 666-676. https:/ / doi.org/10.1187/ cbe.14-01-0003

Deniz, H., \& Borgerding, L. A. (Eds.). (2018). Evolution education around the globe. Springer, Cham.

Deniz, H., \& Sahin, E. A. (2016). Exploring the Factors Related to Acceptance of Evolutionary Theory among Turkish Preservice Biology Teachers and the Relationship between Acceptance and Teaching Preference. Electronic Journal of Science Education, 20(4), 21-43. https://doi.org/10.1007/978-3-31990939-4

Dobzhansky, T. (1973). Nothing in biology makes sense except in light of evolution. The American Biology Teacher, 35(3), 127-129. https://doi.org/10.2307/ 4444260

Eurostat, Education statistics. (n.d.). Retrieved from http:/ / epp.eurostat.ec.europa.eu/statisticsexplain ed/index.php/Educationstatistics\#Compulsoryed ucation

Eurydice. (2019). Slovenia overview. Retrieved from https:/ / eacea.ec.europa.eu/national-policies / eur ydice/content/slovenia_en

Fardisi, M., Gondhalekar, A. D., Ashbrook, A. R., \& Scharf, M. E. (2019). Rapid evolutionary responses to insecticide resistance management interventions by the German cockroach (Blattella germanica L.). Scientific reports, 9(1), 8292. https://doi.org/ 10.1038/s41598-019-44296-y

Fiedler, D., Tröbst, S., \& Harms, U. (2017). University students' conceptual knowledge of randomness and probability in the contexts of evolution and mathematics. CBE-Life Sciences Education, 16(2), ar38. https://doi.org/10.1187/cbe.16-07-0230

Glaze, A., \& Goldston, J. (2019). Acceptance, Understanding \& Experience: Exploring Obstacles to Evolution Education among Advanced Placement Teachers. The American Biology Teacher, 81(2), 71-76. https://doi.org/10.1525/abt.2019.81. 2.71

Gregory, T. R. (2008). Understanding evolutionary trees. Evolution: Education and Outreach, 1(2), 121. https:/ / doi.org/10.1007/s12052-008-0035-x

Gregory, T. R. (2009). Understanding natural selection: essential concepts and common misconceptions. Evolution: Education and outreach, 2(2), 156-175. https: / / doi.org/10.1007/s12052-009-0128-1

Großschedl, J., Mahler, D., \& Harms, U. (2018). Construction and evaluation of an instrument to measure content knowledge in biology: The CKIBI. Education Sciences, 8(3), 145. https:// doi.org/10.3390/educsci8030145

Jeffery, K. R., \& Roach, L. E. (1994). A study of the presence of evolutionary protoconcepts in pre-high school textbooks. Journal of Research in Science Teaching, 31(5), 507-518. https://doi.org/10.1002/ tea.3660310506

Kalinowski, S. T., Leonard, M. J., Andrews, T. M., \& Litt, A. R. (2013). Six classroom exercises to teach natural selection to undergraduate biology students. CBE-Life Sciences Education, 12(3), 483-493. https://doi.org/10.1187/cbe-12-06-0070

Kampourakis, K., \& Zogza, V. (2009). Preliminary evolutionary explanations: A basic framework for conceptual change and explanatory coherence in evolution. Science \& Education, 18(10), 1313-1340. https:/ / doi.org/10.1007/s11191-008-9171-5

Kelemen, D. (2012). Teleological minds: How natural intuitions about agency and purpose influence learning about evolution. In K. S. Rosengren, E. M. Evans, S. Brem, \& G. M. Sinatra (Eds.), Evolution challenges: Integrating research and practice in teaching and learning about evolution (pp. 66-92). New York: Oxford University Press. https:/ / doi.org/10.1093/ acprof:oso/9780199730421.003.0004

Kim, S. Y., \& Nehm, R. H. (2011). A cross-cultural comparison of Korean and American science teachers' views of evolution and the nature of science. International Journal of Science Education, 33(2), 197-227. https://doi.org/10.1080/09500690 903563819

Kubiatko, M., Torkar, G., \& Rovňanová, L. (2017). The Teacher as One of the Factors Influencing Students' Perception of Biology as a School Subject. CEPS Journal, 7(2), 127-140.

Kuschmierz, P., Beniermann, A., \& Graf, D. (2020). Development And Evaluation Of The Knowledge About Evolution 2.0 Instrument (KAEVO 2.0). Manuscript submitted for publication.

Livermore, D. M. (2002). Multiple mechanisms of antimicrobial resistance in Pseudomonas 
aeruginosa: our worst nightmare?. Clinical infectious diseases, 34(5), 634-640. https://doi.org/10.1086/ 338782

Meir, E., Perry, J., Herron, J. C., \& Kingsolver, J. (2007). College students' misconceptions about evolutionary trees. The American Biology Teacher, 69(7), 71-76. https://doi.org/10.1662/00027685(2007)69[71:CSMAET]2.0.CO;2

Meisel, R. P. (2010). Teaching tree-thinking to undergraduate biology students. Evolution: Education and Outreach, 3(4), 621. https:// doi.org/10.1007/s12052-010-0254-9

Moore, R. (2004). How well do biology teachers understand the legal issues associated with the teaching of evolution? BioScience, 54, 860-865. https:// doi.org/10.1641/0006-3568(2004)054[0860: HWDBTU]2.0.CO;2

Nadelson, L. S., \& Nadelson, S. (2010). K-8 educators perceptions and preparedness for teaching evolution topics. Journal of Science Teacher Education, 21(7), 843-858. https://doi.org/10.1007/s10972009-9171-6

Naterer, A., Lavrič, M., Klanjšek, R., Flere, S., Rutar, T., Lahe, D., Kuhar, M., Hlebec, V., Cupar, T., \& Kobše, Ž. (2019). Slovenska mladina 2018/2019 [Slovene youth 2018/2019]. Friedrich-Ebert-Stiftung.

Nehm, R. H., \& Reilly, L. (2007). Biology majors' knowledge and misconceptions of natural selection. BioScience, 57(3), 263-272. https:// doi.org/10.1641/B570311

Nehm, R. H., Kim, S. Y., \& Sheppard, K. (2009). Academic preparation in biology and advocacy for teaching evolution: biology versus non-biology teachers. Science Education, 93(6), 1122-1146. https://doi.org/10.1002/sce.20340

Nehm, R. H., Poole, T. M., Lyford, M. E., Hoskins, S. G., Carruth, L., Ewers, B. E., \& Colberg, P. J. (2009). Does the segregation of evolution in biology textbooks and introductory courses reinforce students' faulty mental models of biology and evolution?. Evolution: Education and Outreach, 2(3), 527-532. https://doi.org/10.1007/s12052-0080100-5

Novick, L. R., \& Catley, K. M. (2013). Reasoning about evolution's grand patterns: College students' understanding of the tree of life. American Educational Research Journal, 50(1), 138-177. https:// doi.org/10.3102/0002831212448209

Novick, L. R., \& Catley, K. M. (2016). Fostering 21stcentury evolutionary reasoning: teaching tree thinking to introductory biology students. $C B E-$ Life Sciences Education, 15(4), ar66. https://doi.org/10.1187/cbe.15-06-0127

Park, J. H. (2007). Persistent misunderstandings of inclusive fitness and kin selection: Their ubiquitous appearance in social psychology textbooks. Evolutionary Psychology, 5(4), 860-873. https:// doi.org/10.1177/147470490700500414

Perry, J., Meir, E., Herron, J. C., Maruca, S., \& Stal, D. (2008). Evaluating two approaches to helping college students understand evolutionary trees through diagramming tasks. CBE-Life Sciences Education, 7(2), 193-201. https://doi.org/10.1187/ cbe.07-01-0007

Pope, D. S., Rounds, C. M., \& Clarke-Midura, J. (2017). Testing the effectiveness of two natural selection simulations in the context of a large-enrollment undergraduate laboratory class. Evolution: Education and Outreach, 10(1), 3. https:/ / doi.org/10.1186/s12052-017-0067-1

Prinou, L., Halkia, L., \& Skordoulis, C. (2011). The inability of primary school to introduce children to the theory of biological evolution. Evolution: Education and Outreach, 4(2), 275. https:// doi.org/10.1007/s12052-011-0323-8

Rachmatullah, A., Nehm, R. H., Roshayanti, F., \& Ha, M. (2018). Evolution Education in Indonesia: Preservice Biology Teachers' Knowledge, Reasoning Models, and Acceptance of Evolution. In Evolution education around the globe (pp. 335-355). Springer, Cham. https://doi.org/10.1007/978-3-319-909394_18

Reiss, M. (2018). Evolution Education in England. In Evolution education around the globe (pp. 155-167). Springer, Cham. https://doi.org/10.1007/978-3319-90939-4_9

Rosengren, K. S., Brem, S. K., Evans, E. M., \& Sinatra, G. M. (Eds.). (2012). Evolution challenges: Integrating research and practice in teaching and learning about evolution. Oxford University Press. https:/ / doi.org/10.1093/acprof:oso/97801997304 21.001.0001

Rutledge, M. L., \& Mitchell, M. A. (2002). High school biology teachers' knowledge structure, acceptance \& teaching of evolution. The American Biology Teacher, 64(1), 21-28. https://doi.org/10.2307/ 4451231

Sickel, A. J., \& Friedrichsen, P. (2013). Examining the evolution education literature with a focus on teachers: major findings, goals for teacher preparation, and directions for future research. Evolution: Education and Outreach, 6(1), 23. https:/ / doi.org/10.1186/1936-6434-6-23

Skoog, G. (2005). The coverage of human evolution in high school biology textbooks in the 20th century and in current state science standards. Science $\mathcal{E}$ Education, 14(3-5), 395-422. https://doi.org/ 10.1007/s11191-004-5611-z

Šorgo, A., Usak, M., Kubiatko, M., Fančovičova, J., Prokop, P., Puhek, M., Skoda, J., \& Bahar. M. (2014). 
A Cross-cultural Study on Freshmen's Knowledge of Genetics, Evolution, and the Nature of Science. Journal of Baltic Science Education, 13(1), 6-18.

Stern, F., Kampourakis, K., Huneault, C., Silveira, P., \& Müller, A. (2018). Undergraduate biology students' teleological and essentialist misconceptions. Education Sciences, 8(3), 135. https://doi.org/ 10.3390/educsci8030135

Tavares, G. M., \& Bobrowski, V. L. (2018). Integrative assessment of Evolutionary theory acceptance and knowledge levels of Biology undergraduate students from a Brazilian university. International Journal of Science Education, 40(4), 442-458. https: / / doi.org/10.1080/09500693.2018.1429031

Trani, R. (2004). I won't teach evolution; it's against my religion. And now for the rest of the story... The American Biology Teacher, 66(6), 419-427. https: / / doi.org/10.1662/0002-7685(2004)066[0419: IWTIAM]2.0.CO;2

Vaughn, A. R., \& Robbins, J. R. (2017). Preparing Preservice K-8 Teachers for the Public School: Improving Evolution Attitudes, Misconceptions, and Legal Confusion. Journal of College Science Teaching, 47(2), 7-15. https://doi.org/10.2505/4/ jcst17_047_02_7

Wagler, R. (2010). A missing link: K-4 biological evolution content standards. Evolution: Education and Outreach, 3(3), 443. https://doi.org/ 10.1007/s12052-010-0240-2

Walter, E. M., Halverson, K. M., \& Boyce, C. J. (2013). Investigating the relationship between college students' acceptance of evolution and tree thinking understanding. Evolution: Education and Outreach, 6(1), 26. https:/ / doi.org/10.1186/1936-6434-6-26

Winegard, B. M., Winegard, B. M., \& Deaner, R. O. (2014). Misrepresentations of evolutionary psychology in sex and gender textbooks. Evolutionary Psychology, 12(3), 474-508. https:/ / doi.org/10.1177/147470491401200301

Yok, M. C. K., Clément, P., Leong, L. K., Shing, C. L., \& Ragem, P. A. (2015). Preliminary results on Malaysian teachers conception of evolution. Procedia-Social and Behavioral Sciences, 167, 250-255. https:// doi.org/10.1016/j.sbspro.2014.12.670

\section{APPENDIX}

Table 1. Religiosity of students (PERF scale; Beniermann, 2019)

\begin{tabular}{|c|c|c|c|c|c|c|c|c|}
\hline Items & 1 & 2 & 3 & 4 & 5 & Missing & $M$ & $S D$ \\
\hline 1. I believe in God. & $\begin{array}{c}96 \\
(35.7)\end{array}$ & $\begin{array}{c}60 \\
(22.3)\end{array}$ & $\begin{array}{c}43 \\
(16.0)\end{array}$ & $\begin{array}{c}16 \\
(5.9)\end{array}$ & $\begin{array}{c}47 \\
(17.5)\end{array}$ & $\begin{array}{c}7 \\
(2.6)\end{array}$ & 2.46 & 1.48 \\
\hline 2. I feel that God exists. & $\begin{array}{c}81 \\
(30.1)\end{array}$ & $\begin{array}{c}54 \\
(20.1)\end{array}$ & $\begin{array}{c}54 \\
(20.1)\end{array}$ & $\begin{array}{c}16 \\
(5.9)\end{array}$ & $\begin{array}{c}57 \\
(21.2)\end{array}$ & $\begin{array}{c}7 \\
(2.6)\end{array}$ & 2.67 & 1.51 \\
\hline $\begin{array}{l}\text { 3. I think there are good arguments that confirm the } \\
\text { existence of God. }\end{array}$ & $\begin{array}{c}44 \\
(16.4)\end{array}$ & $\begin{array}{c}64 \\
(23.8)\end{array}$ & $\begin{array}{c}66 \\
(24.5)\end{array}$ & $\begin{array}{c}27 \\
(10.0)\end{array}$ & $\begin{array}{c}61 \\
(22.7)\end{array}$ & $\begin{array}{c}7 \\
(2.6)\end{array}$ & 2.99 & 1.40 \\
\hline 4. I would describe myself as a religious person. & $\begin{array}{c}77 \\
(28.6)\end{array}$ & $\begin{array}{c}59 \\
(21.9)\end{array}$ & $\begin{array}{c}44 \\
(16.4)\end{array}$ & $\begin{array}{c}25 \\
(9.3)\end{array}$ & $\begin{array}{c}57 \\
(21.2)\end{array}$ & $\begin{array}{c}7 \\
(2.6)\end{array}$ & 2.72 & 1.52 \\
\hline 5. Without faith, my life would be meaningless. & $\begin{array}{c}33 \\
(12.3)\end{array}$ & $\begin{array}{c}43 \\
(16.0)\end{array}$ & $\begin{array}{c}70 \\
(26.0)\end{array}$ & $\begin{array}{c}32 \\
(11.9)\end{array}$ & $\begin{array}{c}83 \\
(30.9)\end{array}$ & $\begin{array}{c}7 \\
(2.6)\end{array}$ & 3.34 & 1.40 \\
\hline 6. I believe that haven exists. & $\begin{array}{c}66 \\
(24.5)\end{array}$ & $\begin{array}{c}46 \\
(17.1)\end{array}$ & $\begin{array}{c}66 \\
(24.5)\end{array}$ & $\begin{array}{l}18 \\
(6.7)\end{array}$ & $\begin{array}{c}63 \\
(23.4)\end{array}$ & $\begin{array}{c}7 \\
(2.6)\end{array}$ & 2.87 & 1.49 \\
\hline $\begin{array}{l}\text { 7. I pray in faith that my prayers will change events } \\
\text { in the future. }\end{array}$ & $\begin{array}{c}49 \\
(18.2)\end{array}$ & $\begin{array}{c}62 \\
(23.0)\end{array}$ & $\begin{array}{c}56 \\
(20.8)\end{array}$ & $\begin{array}{c}27 \\
(10.0)\end{array}$ & $\begin{array}{c}66 \\
(24.5)\end{array}$ & $\begin{array}{c}9 \\
(3.3)\end{array}$ & 3.00 & 1.46 \\
\hline 8. I feel fulfilled when I am in the presence of God. & $\begin{array}{c}37 \\
(13.8)\end{array}$ & $\begin{array}{c}53 \\
(19.7)\end{array}$ & $\begin{array}{c}69 \\
(25.7)\end{array}$ & $\begin{array}{c}24 \\
(8.9)\end{array}$ & $\begin{array}{c}79 \\
(29.4)\end{array}$ & $\begin{array}{c}7 \\
(2.6)\end{array}$ & 3.21 & 1.42 \\
\hline $\begin{array}{l}\text { 9. Because of faith, I have the hope that I will live } \\
\text { after death. }\end{array}$ & $\begin{array}{c}55 \\
(20.4)\end{array}$ & $\begin{array}{c}32 \\
(11.9)\end{array}$ & $\begin{array}{c}63 \\
(23.4)\end{array}$ & $\begin{array}{c}26 \\
(9.7)\end{array}$ & $\begin{array}{c}84 \\
(31.2)\end{array}$ & $\begin{array}{c}9 \\
(3.3)\end{array}$ & 3.20 & 1.53 \\
\hline 10. My life makes sense because God wants me. & $\begin{array}{c}36 \\
(13.4)\end{array}$ & $\begin{array}{c}42 \\
(15.6)\end{array}$ & $\begin{array}{c}73 \\
(27.1)\end{array}$ & $\begin{array}{c}23 \\
(8.6)\end{array}$ & $\begin{array}{c}88 \\
(32.7) \\
\end{array}$ & $\begin{array}{c}7 \\
(2.6) \\
\end{array}$ & 3.32 & 1.43 \\
\hline
\end{tabular}

